\title{
Fruit polyphenols and CVD risk: a review of human intervention studies
}

\author{
Mary F.-F. Chong, Rory Macdonald and Julie A. Lovegrove* \\ Hugh Sinclair Unit of Human Nutrition and Institute for Cardiovascular and Metabolic Research, Department of Food and \\ Nutritional Sciences, University of Reading, Whiteknights, PO Box 266, Reading, Berkshire RG6 6AP, UK
}

(Received 11 February 2010 - Revised 7 May 2010 - Accepted 2 June 2010)

Epidemiological evidence suggests that polyphenols may, in part, explain the cardioprotective properties of fruits. This review aims to summarise the evidence for the effects of fruit polyphenols on four risk factors of CVD: platelet function, blood pressure, vascular function and blood lipids. This review includes human dietary intervention studies investigating fruits and their polyphenols. There was some evidence to suggest that fruits containing relatively high concentrations of flavonols, anthocyanins and procyanindins, such as pomegranate, purple grapes and berries, were effective at reducing CVD risk factors, particularly with respect to anti-hypertensive effects, inhibition of platelet aggregation and increasing endothelial-dependent vasodilation than other fruits investigated. Flavanone-rich fruits, such as oranges and grapefruits, were reported to have hypocholesterolaemic effects, with little impact on other risk factors being examined. However, the evidence was limited, inconsistent and often inconclusive. This is in part due to the heterogeneity in the design of studies, the lack of controls, the relatively short intervention periods and low power in several studies. Details of the polyphenol content of the fruits investigated were also omitted in some studies, negating comparison of data. It is recommended that large, well-powered, long-term human dietary intervention studies investigating a wider range of fruits are required to confirm these observations. Investigations into the potential synergistic effects of polyphenols on a combination of CVD risk markers, doseresponse relationships and standardisation in methodology would facilitate the comparison of studies and also provide valuable information on the types of fruits which could confer protection against CVD.

Fruits: Polyphenols: CVD: Human

CVD is responsible for nearly half of all deaths (48\%) each year in Europe. With its high mortality and morbidity, CVD is estimated to cost the European Union $€ 192$ billion a year $^{(1)}$. Mounting evidence from epidemiological studies suggests that there is an association between diets rich in fruits and vegetables and a reduction in the incidence of $\mathrm{CVD}^{(2,3)}$. Fruits and vegetables contain a wide range of potentially cardioprotective components including fibre, folate, antioxidants, vitamins and a large number of non-nutrient phytochemicals such as carotenoids and polyphenols. However, the contribution of these components to cardiovascular protection is far from clear. The total intake of polyphenols in the diet can be as high as $1 \mathrm{~g} / \mathrm{d}$ in some population groups, which in absolute terms is the highest among all the classes of phytochemicals ${ }^{(4)}$. Epidemiological evidence suggests that polyphenols may, in part, explain the CVD benefits of increased fruit and vegetable intake ${ }^{(5,6)}$. A recent prospective study reported that the specific flavonoid-rich foods associated with lower CVD mortality included apples, pears, grapefruit, strawberries, chocolate and bran ${ }^{(7)}$. This highlights the potential importance of fruits as a cardioprotective food, worthy of further investigation.

There is a plethora of experimental studies in the literature examining the effects of various polyphenol subclasses on biological systems in vitro and in animal models. However, extrapolation of these data to the human is fraught with problems, predominantly because the bioavailability and metabolism of the different classes of polyphenols vary widely between animals ${ }^{(8)}$. It is thus imperative to conduct human intervention studies to elucidate the actual effects of these compounds. To date, the majority of dietary intervention studies have focussed on polyphenolic-rich beverages including tea, cocoa and red wine ${ }^{(9,10)}$. Intervention studies on fruits are comparatively few in number. Although some fruit polyphenol subclasses are present in the well-investigated foods, e.g. procyanidins in chocolate, their structure may vary in different food matrices or when combined with other polyphenols $^{(10)}$.

The impact of fruit polyphenols on CVD mortality is of considerable public health importance and would help to inform policy on recommendations of the types of fruits to be consumed for CVD reduction. Due to lack of studies with hard endpoints such as CVD mortality, human intervention studies investigating the impact of different fruit polyphenols on known CVD risk factors were considered in this review. Four specific risk markers were described, namely platelet function, hypertension, lipid metabolism and vascular function. These risk markers were chosen due to their independent association with CVD and the availability of relevant studies investigating the impact of fruit polyphenols.

Abbreviations: BP, blood pressure; CIMT, carotid intima-media thickness; MeSH, Medical Subject Heading; SBP, systolic blood pressure.

* Corresponding author: Professor J. A. Lovegrove, fax +4401189310080, email j.a.lovegrove@reading.ac.uk 
Brief comment on their importance in CVD development follows. Increased platelet activity and therefore platelet aggregation can potentially further the development and progression of CVD. A heightened susceptibility of platelets to aggregate contributes to the initiation and progression of atherosclerosis and to the occurrence of thrombotic events $^{(11,12)}$. Another established and independent risk factor of CVD is hypertension (high blood pressure (BP)), which has also been recognised as a major modifiable cause of death in both the developed and developing world ${ }^{(13)}$. Hypertension is defined as systolic BP (SBP) of greater than $140 \mathrm{mmHg}$ or diastolic BP of greater than $90 \mathrm{mmHg}$. A reduction in the entire distribution of $\mathrm{BP}$ in the population by $5 \mathrm{mmHg}$ has been hypothesised to produce a $40 \%$ decrease in the incidence of stroke and a $20-25 \%$ reduction in $\mathrm{CHD}^{(14-16)}$. There is also indisputable evidence that elevated plasma cholesterol, particularly LDL-cholesterol, elevated plasma TAG and low plasma HDL-cholesterol levels are independently associated with increased CVD risk $^{(17)}$. It has been estimated that $45 \%$ of heart attacks in Western Europe are due to abnormal lipid profile ${ }^{(18)}$, and that examining the complete lipoprotein profile of a person is advised to determine an individual's risk of CVD. The vascular endothelium plays a key role in the regulation of vascular homeostasis, and alterations in endothelial function contribute to the pathogenesis and clinical expression of $\mathrm{CVD}^{(19)}$. Many factors impact adversely on the endothelium including dyslipidaemia, hypertension, diabetes mellitus, smoking, aging, physical inactivity, systemic inflammation and insulin resistance. Genetic and environmental factors also influence the impact of these risk factors on endothelial function with evidence for a key role of dietary factors in modulating endothelial function. Prospective studies have confirmed the association between endothelial function and an increased risk of CVD events ${ }^{(20)}$. Findings from these studies suggest that vascular function may be a valuable holistic surrogate marker of CVD risk, and it is becoming increasingly accepted as a clinical measure and outcome marker of CVD in various research studies ${ }^{(21)}$.

\section{Methodology}

\section{Search strategy}

A structured approach was adopted to ensure optimal retrieval of relevant articles in the electronic search of PubMed database to September 2009. Medical Subject Heading (MeSH) terms were used to identify relevant exposures and outcome terms (see supplementary material at http://www.journals. cambridge.org/bjn for terms used). The search strategy was adapted from Dangour et al. ${ }^{(2)}$, and the following search protocol was used: ((flavonoid-rich food exposure $\mathrm{MeSH}$ terms and text terms) OR (definition of polyphenols exposure $\mathrm{MeSH}$ and text terms)) AND outcome MeSH and text terms grouped in categories. Text terms were used when terms were not included in the MeSH database as a $\mathrm{MeSH}$ term. The outcome terms were grouped into categories to cover the four selected risk factors of CVD. A combination of MeSH and text terms was used in each outcome category. References in the journal articles and relevant reviews were hand searched to locate additional relevant studies.
All languages were included in the search, but only papers with English abstracts were used for the review.

\section{Study selection and data extraction}

Four hundred and eighty-two abstracts were identified from the searches. After deleting duplicates and excluding irrelevant abstracts and reviews, 151 abstracts were classed as relevant. Studies investigating polyphenols in wine were not included. Although wine polyphenols are predominantly derived from grapes, alcohol itself can independently influence cardiovascular risk ${ }^{(23)}$. Moreover, the literature on wine polyphenols is diverse and by itself an area to be reviewed separately ${ }^{(24)}$. Studies that primarily investigated the bioavailability of individual polyphenol compounds, without reporting any biological effects, or those studies reporting laboratory methods to detect certain polyphenols were considered irrelevant and excluded. In addition, studies investigating polyphenols derived from other plant parts such as leaf and bark were not included in this review. Studies investigating the impact of both fruits and vegetables were also excluded, as it was not possible to determine the contribution of the fruit component of the diet on the observed CVD risk markers.

All searching and data extraction were conducted by a research assistant (R. M.) and the first author (M. F.-F. C.), and any disagreement was resolved in discussion with the project lead (J. A. L.). Data extraction was carried out in duplicate for the first ten articles of each outcome category, and inconsistencies were discussed and consensus reached. Data from the other articles were entered by the research assistant and checked by the first author.

All relevant abstracts were then grouped into the four outcome categories each subdivided into human, animal or in vitro studies. The relevant papers identified by this search included human intervention trials investigating the impact of fruit polyphenols on blood lipids ( $n$ 17), platelet function ( $n$ 9), BP ( $n$ 9) and endothelium-dependent vasodilation (vascular function) ( $n$ 7). The review is structured into four sections: platelet function, BP, vascular reactivity and blood lipids.

\section{Results}

\section{Platelet aggregation}

The effects of fruit polyphenols on platelet aggregation in human intervention studies are shown in Table 1 . The most commonly investigated fruit was grape. The studies were of chronic design in which platelet aggregation was determined ex vivo, and grape juice was given for a period of $7-28 \mathrm{~d}$ to healthy subjects. Blood samples were taken at varying times, and the ex vivo platelet aggregation was determined using differing agonists and techniques. Based on an estimation for a $60 \mathrm{~kg}$ person, the average grape juice intake ranged from 300 to $500 \mathrm{ml} / \mathrm{d}$. Results from these studies have supported the hypothesis that purple, but not red, grape juice is effective in inhibiting platelet aggregation, despite adopting different methods of measuring platelet aggregation response ${ }^{(25,26)}$.

Other fruits and fruit juices which have been reported to have significant inhibitory effects on platelet aggregation 
Table 1. Effects of fruit polyphenols on platelet aggregation in human intervention studies*

\begin{tabular}{|c|c|c|c|c|c|c|c|c|}
\hline References & Study design & Substance given & Principal polyphenol† & Dose/d & Days & Subjects & Biomarkers & Effects $\ddagger$ \\
\hline $\begin{array}{l}\text { Pace-Asciak } \\
\text { et } \text { al. }^{\left({ }^{2}\right)}\end{array}$ & $\begin{array}{l}\text { Chronic, } \\
\text { crossover }\end{array}$ & Red GJ & & $500 \mathrm{ml}$ & 28 & $\begin{array}{l}\text { Twenty-four } \\
\text { healthy }\end{array}$ & $\begin{array}{l}\text { Platelet aggre. (ADP and } \\
\text { thrombin) }\end{array}$ & $\leftrightarrow$ \\
\hline $\begin{array}{l}\text { Keevil } \\
\quad \text { et al. }\end{array}$ & $\begin{array}{l}\text { Chronic, } \\
\text { crossover, } \\
\text { dose response }\end{array}$ & $\begin{array}{l}\text { Purple GJ or } \\
\text { OJ or GFJ }\end{array}$ & & $\begin{array}{l}5-7.5 \mathrm{ml} / \mathrm{kg} \\
\text { body wt }\end{array}$ & $7-10$ & Ten healthy & $\begin{array}{l}\text { Platelet aggre. } \\
\text { (collagen) for GJ } \\
\text { Platelet aggre. (collagen) for } \\
\text { OJ and GFJ } \\
\text { Platelet aggre. (thrombin and ADP) } \\
\text { for all juices }\end{array}$ & $\begin{array}{l}\downarrow(77 \%) \\
\leftrightarrow\end{array}$ \\
\hline $\begin{array}{l}\text { Freedman } \\
\text { et al. }\end{array}$ & $\begin{array}{l}\text { Chronic, single } \\
\text { arm, no control }\end{array}$ & Purple GJ (Welch's) & $\begin{array}{l}\text { Cinnamic acids, } \\
\text { anthocyanins }\end{array}$ & $7 \mathrm{ml} / \mathrm{kg}$ body wt & 14 & $\begin{array}{l}\text { Twenty } \\
\text { healthy }\end{array}$ & $\begin{array}{l}\text { Platelet aggre. (ADP and collagen) } \\
\text { Platelet-derived NO release }\end{array}$ & $\begin{array}{l}\downarrow(19.6 \%) \\
\uparrow(71 \%)\end{array}$ \\
\hline $\begin{array}{l}\text { Polagruto } \\
\text { et al. }\end{array}$ & $\begin{array}{l}\text { Acute, controlled } \\
\text { parallel }\end{array}$ & $\begin{array}{l}\text { Flavonol-rich } \\
\text { grape seed extract }\end{array}$ & Flavonols & $400 \mathrm{mg}$ & 1 & $\begin{array}{l}\text { Thirteen male } \\
\text { smokers }\end{array}$ & $\begin{array}{l}\text { Platelet aggre. (ADP) } \\
\text { at } 1,2 \text { and } 6 \mathrm{~h} \\
\text { Platelet aggre. } \\
\text { epinephrine-stimulated } \\
\text { at } 2 \mathrm{~h} \text { only (bloods taken } \\
\text { at } 0,1,2 \text { and } 6 \mathrm{~h} \text { ) }\end{array}$ & $\downarrow$ \\
\hline $\begin{array}{l}\text { Aviram } \\
\quad \text { et al. }\end{array}$ & $\begin{array}{l}\text { Chronic, single arm, } \\
\text { no control }\end{array}$ & Pomegranate juice & $\begin{array}{l}\text { Tannins, } \\
\text { anthocyanins }\end{array}$ & $50 \mathrm{ml}$ & 14 & Thirteen healthy & Platelet aggre. (collagen) & $\downarrow(11 \%)$ \\
\hline $\begin{array}{l}\text { Eccleston } \\
\quad \text { et al. }\end{array}$ & $\begin{array}{l}\text { Chronic, controlled } \\
\text { crossover }\end{array}$ & Sea buckthorn juice & $\begin{array}{l}\text { Isorhamnetin- } \\
\text { rutinoside }\end{array}$ & $300 \mathrm{ml}$ daily & 56 & Twenty healthy & $\begin{array}{l}\text { Whole blood aggre. } \\
\text { (ADP or AA) } \\
\text { Whole blood aggre. } \\
\text { ( } 1.5 \text { or } 5 \mu \mathrm{g} / \mathrm{ml} \\
\text { collagen) }\end{array}$ & $\begin{array}{l}\leftrightarrow \\
\leftrightarrow\end{array}$ \\
\hline $\begin{array}{l}\text { Erlund } \\
\quad \text { et al. }\end{array}$ & $\begin{array}{l}\text { Chronic, controlled } \\
\text { crossover }\end{array}$ & $\begin{array}{l}\text { A combination of bilberries, } \\
\text { lingonberries, blackcurrant } \\
\text { and strawberry puree and } \\
\text { raspberry juice }\end{array}$ & Anthocyanins & $150 \mathrm{~g}$ & 56 & $\begin{array}{l}\text { Seventy-two } \\
\text { subjects } \\
\text { with CVD } \\
\text { risk factors }\end{array}$ & $\begin{array}{l}\text { Platelet function } \\
\text { (ADP and collagen) } \\
\text { Plasma biomarkers } \\
\text { of platelet activation } \\
\text { and coagulation }\end{array}$ & $\begin{array}{l}\downarrow(11 \%) \\
\leftrightarrow\end{array}$ \\
\hline
\end{tabular}

Platelet aggre. (agonist), platelet aggregation (agonist/s used to stimulate aggregation); AA, arachidonic acid; GJ, grape juice; OJ, orange juice; GFJ, grapefruit juice.

* Table is arranged by similar fruit type, followed by year in ascending order of fruits investigated by a single study.

† Only the top two polyphenols with the highest concentrations reported in the reference papers are listed.

$\ddagger \uparrow$ refers to increase; $\downarrow$ refers to decrease; $\leftrightarrow$ refers to no change; unless otherwise stated, $(\%)$ refers to changes from baseline when test substance given

$\S$ Reference papers for details of data. 
included pomegranate juice $(50 \mathrm{ml} / \mathrm{d} \text { for } 14 \mathrm{~d})^{(27)}$, grape seed extract (acute study) ${ }^{(28)}$ and a combination of various berries (bilberries, lingonberries, blackcurrant puree, strawberry puree and raspberry juice) ${ }^{(29)}$, although evidence for the latter is not as convincing. The major polyphenol compounds present in the fruit juices and fruits, which were reported to have bioactivity in relation to platelet activity, were anthocyanins, phenolic acids, flavonols (quercetin) and procyanidins. Conversely, orange juice, grapefruit juice and sea buckthorn juice had no reported effects on platelet aggregation ${ }^{(26,30)}$.

It is interesting to note that when quercetin (found at high levels in apples) was isolated and chronically consumed as a supplement or soup ${ }^{(31,32)}$, it did not significantly affect platelet aggregation. This is despite doses in the supplement being almost ten times greater than that in foods ${ }^{(31)}$. Moreover, there is increasing evidence from in vitro studies indicating that anti-platelet effects are greater when a combination of polyphenolic compounds were used than when used individually ${ }^{(25,33,34)}$. Shanmuganayagam et al. compared the effect of extracts of grape seed and grape skin individually and in combination on platelet aggregation. While grape seed extract inhibited platelet aggregation by $12.7 \%$, grape skin extract did not; yet the combination of both the extracts inhibited platelet aggregation to a greater extent $(40 \cdot 5 \%)$. It is speculated that the observed enhancement of the anti-platelet effect may be due to the interaction of specific procyanidins unique to the grape seed extract, with the phenolic compounds being found in the grape skin extract ${ }^{(34)}$. In another study, anthocyanins and in vivo metabolites of different polyphenols of colonic origin, and a representative mixture of both at physiological concentrations, were compared. It was observed that the representative mixture was more effective in attenuating platelet aggregation than the individual components. This was despite the mixture containing ten times lower concentrations than that of the individual components ${ }^{(33)}$. This synergistic relationship between certain polyphenolic compounds may explain why fruits or fruit juices, which contain a combination of polyphenols, are more effective than isolated polyphenols.

The potency of different classes of polyphenols in inhibiting platelet aggregation may be another explanation for the variable reported results. In vitro studies have reported that flavonols (found in grape juice) were more potent antioxidants and anti-platelet agents than flavanones (abundant in citrus fruits $)^{(35)}$. This may provide the explanation for a significant reduction in whole blood platelet aggregation response when purple grape juice was consumed compared with the lack of response observed with the same volume of orange or grapefruit juice when ingested ${ }^{(26)}$. Whether this differential impact on platelet aggregation is influenced in part by the difference in bioavailability of the two classes of flavonoid compounds is unknown and remains to be investigated.

In addition to the differential effect of subclasses of flavonoids in relation to platelet aggregation, the concentration of these compounds in the foods is a key to their effect on platelet function. Orange and grapefruit juice have threefold lower total polyphenolic content than purple grape juice, while red grape juice has lower total polyphenols than purple grape juice $^{(26)}$. It is difficult to determine whether the total polyphenolic content, the specific subclass of flavonoid or a combination of the two determine the effect on platelet aggregation. This is mainly because there is an absence of information regarding the polyphenolic content of foods in some studies ${ }^{(25,36)}$ and where concentrations were reported, comparison could be confounded by the different methods used to analyse total polyphenolic content. For example, Keevil et al. ${ }^{(26)}$ measured total phenolic content of the juices using the Folin-Ciocaltru assay and performed a qualitative analysis of the major types of flavonoid present, while Erlund et al. ${ }^{(29)}$ quantified total polyphenolic content using HPLC after alkaline and acid hydrolysis. Aviram et al. ${ }^{(27)}$ used a different method again, determining the total polyphenol concentration spectrophotometrically with phosphomolybdic-phosphotungstic acid reagent and quercetin as a standard.

There were other methodological differences postulated to account for the differential results among studies. It appears that studies measuring ex vivo platelet effects during fasting conditions usually gave negative findings ${ }^{(29,31,37)}$ in contrast to those measuring postprandial platelet effects ${ }^{(26,28,38,39)}$. An example is quercetin which when consumed chronically as a supplement ${ }^{(31)}$ had no effect on ex vivo platelet aggregation. In contrast, Hubbard et al. ${ }^{(38,39)}$ reported a significant reduction in ex vivo platelet aggregation after acute ingestion of quercetin as quercetin- $4^{\prime}-O$ - $\beta$-D-glucoside supplement (150 and $300 \mathrm{mg}$ ) and in the form of onion soup (70 mg of total quercetin) compared with a control. Whether the presence of most dietary flavonoids, during fasting conditions, is too low to modulate in vivo platelet function remains to be determined, although there is evidence that the peak plasma concentration of flavonoids is between 1 and $3 \mathrm{~h}$ and that they are metabolised and excreted within $8-12 \mathrm{~h}^{(38)}$. There is also the possible confounding effect of using different samples for platelet aggregation determination: whole blood platelets or plateletrich plasma, which do not necessarily give similar results ${ }^{(30)}$. Finally, it appears that the inhibitory effect of a food substance can be significantly influenced by the type and amount of agonist used to stimulate platelet aggregation, and thus affects the outcomes of studies ${ }^{(40)}$.

\section{Blood pressure}

There is evidence suggesting that the consumption of fruits containing high amounts of flavonoids leads to lower BP and may provide protection against CVD and stroke ${ }^{(41)}$. This is supported by a study that identified that flavonoid-rich food consumption was inversely related to SBP in women $^{(42)}$. The effects of fruit polyphenols on BP in human intervention studies are shown in Table 2. Among the range of fruits studied, pomegranate was the most commonly investigated. Three studies determined the impact of pomegranate juice on subjects who had clinical signs of CVD and on a range of medication. A consistent $5 \%$ reduction in SBP was reported when Aviram et al. ${ }^{(27)}$ gave $50 \mathrm{ml} / \mathrm{d}$ pomegranate juice to a small number of hypertensives ( $n 10)$, and a significant $21 \%$ reduction in SBP was observed when the same volume of juice was given to a larger group of participants (n 19) with asymptomatic severe carotid artery stenosis for a year. In contrast, Sumner and colleagues reported no effect on BP after $240 \mathrm{ml} / \mathrm{d}$ of pomegranate juice (a larger volume than Aviram's) was consumed for a longer length of time $(90 \mathrm{~d})$ in a much larger group of participants ( $n$ 45) with ischaemic coronary disease, although this was associated 
Table 2. Effects of fruit polyphenols on blood pressure in human intervention studies*

\begin{tabular}{|c|c|c|c|c|c|c|c|c|}
\hline References & Study design & Substance given & Principal polyphenol† & Dose/d & Days & Subjects & Biomarkers & Effects $\ddagger$ \\
\hline $\begin{array}{l}\text { Aviram \& } \\
\quad \text { Dornfeld }^{(66)}\end{array}$ & $\begin{array}{l}\text { Chronic, single arm, } \\
\text { no control }\end{array}$ & Pomegranate juice & $\begin{array}{l}\text { Tannins, } \\
\text { anthocyanins }\end{array}$ & $50 \mathrm{ml}$ & 14 & Ten hypertensives & $\begin{array}{l}\text { SBP } \\
\text { serum ACE }\end{array}$ & $\begin{array}{l}\downarrow(5 \%) \\
\downarrow(36 \%)\end{array}$ \\
\hline $\begin{array}{l}\text { Aviram } \\
\text { et al. } .^{(53)}\end{array}$ & $\begin{array}{l}\text { Chronic, } \\
\text { controlled parallel }\end{array}$ & Pomegranate juice & $\begin{array}{l}\text { Tannins, } \\
\text { anthocyanins }\end{array}$ & $50 \mathrm{ml}$ & $1-3$ years & $\begin{array}{l}\text { Nineteen } \\
\text { patients with } \\
\text { asymptomatic } \\
\text { severe carotid } \\
\text { artery stenosis }\end{array}$ & $\begin{array}{l}\text { SBP (after } 1 \text { year) } \\
\text { SBP (after } 3 \text { years) } \\
\text { DBP }\end{array}$ & $\begin{array}{l}\perp(21 \%) \\
\text { No further } \\
\quad \text { reduction } \\
\leftrightarrow\end{array}$ \\
\hline $\begin{array}{l}\text { Sumner } \\
\text { et al. }{ }^{(61)}\end{array}$ & $\begin{array}{l}\text { Chronic, controlled } \\
\text { parallel }\end{array}$ & Pomegranate juice & $\begin{array}{l}\text { Tannins, } \\
\text { anthocyanins }\end{array}$ & $240 \mathrm{ml}$ & 90 & $\begin{array}{l}\text { Forty-five with } \\
\text { ischaemic coronary } \\
\text { disease and } \\
\text { myocardial } \\
\text { Ischaemia }\end{array}$ & $\mathrm{BP}$ & $\leftrightarrow$ \\
\hline $\begin{array}{l}\text { Ruel } \\
\quad \text { et al. }\end{array}$ & $\begin{array}{l}\text { Chronic, single arm, } \\
\text { no control }\end{array}$ & Cranberry juice & & $7 \mathrm{ml} / \mathrm{kg}$ body wt & 14 & Twenty-one healthy & SBP & $\begin{array}{l}\downarrow \text { ( } 2 \% \text { but not } \\
\text { statistically } \\
\text { significant) }\end{array}$ \\
\hline $\begin{array}{l}\text { Wilson } \\
\quad \text { et al. }{ }^{(45)}\end{array}$ & $\begin{array}{l}\text { Acute, controlled } \\
\text { parallel }\end{array}$ & $\begin{array}{l}\text { Cranberry extract } \\
\text { or other beverage }\end{array}$ & $\begin{array}{l}\text { Anthocyanins, } \\
\text { phenolic acids }\end{array}$ & $480 \mathrm{ml}$ & Postprandial & 187 healthy & $\begin{array}{l}\text { BP } \\
\text { Heart rate (both } \\
\quad \text { taken at } 0,30,60, \\
120 \text { and } 180 \mathrm{~min})\end{array}$ & $\stackrel{\leftrightarrow}{\leftrightarrow}$ \\
\hline $\begin{array}{r}\text { Gorinstein } \\
\text { et al. }{ }^{(43)}\end{array}$ & $\begin{array}{l}\text { Chronic, controlled } \\
\text { parallel }\end{array}$ & $\begin{array}{c}\text { Blond or red } \\
\text { grapefruit }\end{array}$ & $\begin{array}{l}\text { Flavonoids, } \\
\text { anthocyanins }\end{array}$ & One fruit & 30 & $\begin{array}{l}\text { Fifty-seven } \\
\text { hyperlipidaemics } \\
\text { after coronary } \\
\text { bypass surgery }\end{array}$ & $\begin{array}{l}\text { SBP } \\
\text { DBP }\end{array}$ & $\stackrel{\leftrightarrow}{\leftrightarrow}$ \\
\hline $\begin{array}{l}\text { Naruszewicz } \\
\quad \text { et al. }\end{array}$ & $\begin{array}{l}\text { Chronic, controlled } \\
\text { parallel }\end{array}$ & $\begin{array}{l}\text { Chokeberry } \\
\text { flavonoid extract }\end{array}$ & $\begin{array}{l}\text { Anthocyanins, } \\
\text { procyanidins }\end{array}$ & $3 \times 85 \mathrm{mg}$ & 42 & $\begin{array}{l}\text { Forty-four } \\
\text { myocardial } \\
\text { infarction } \\
\text { survivors on } \\
\text { statins for } \\
6 \text { months }\end{array}$ & $\begin{array}{l}\text { SBP } \\
\text { DBP } \\
\text { serum ACE }\end{array}$ & $\begin{array}{l}\downarrow(7.2 \mathrm{mmHg}) \\
\downarrow(11 \mathrm{mmHg}) \\
\downarrow(33.3 \%)\end{array}$ \\
\hline $\begin{array}{l}\text { Borochov-Neori } \\
\text { et al. }{ }^{(46)}\end{array}$ & $\begin{array}{l}\text { Chronic, single arm, } \\
\text { no control }\end{array}$ & Marula juice & $\begin{array}{l}\text { Hydrolysable } \\
\text { tannins, catechins }\end{array}$ & $200 \mathrm{ml}$ & 21 & Ten healthy & $\mathrm{BP}$ & $\leftrightarrow$ \\
\hline $\begin{array}{l}\text { Erlund } \\
\text { et al. }\end{array}$ & $\begin{array}{l}\text { Chronic, controlled } \\
\text { crossover }\end{array}$ & $\begin{array}{l}\text { A combination of } \\
\text { bilberries, } \\
\text { lingonberries, } \\
\text { blackcurrant } \\
\text { and strawberry } \\
\text { puree and } \\
\text { raspberry juice }\end{array}$ & Anthocyanins & $150 \mathrm{~g}$ & 56 & $\begin{array}{l}\text { Seventy-two } \\
\text { subjects with } \\
\text { CVD risk factors }\end{array}$ & SBP & $\begin{array}{l}\downarrow \text { by } 7.3 \mathrm{mmHg} \\
\text { in subjects } \\
\text { with high baseline } \\
\mathrm{BP} \text { in the } \\
\text { treatment group }\end{array}$ \\
\hline
\end{tabular}

SBP, systolic blood pressure; serum ACE, plasma angiotensin 1-converting enzyme; DBP, diastolic blood pressure; BP, blood pressure.

* Table is arranged by similar fruit type, followed by year in ascending order of fruits investigated by a single study.

† refers to increase; $\downarrow$ refers to decrease; $\leftrightarrow$ refers to no change; unless otherwise stated, $(\%)$ refers to changes from baseline when test substance given. 
with a reduction in stress-induced ischaemia instead ${ }^{(43)}$. The explanation for these discrepant results is unclear and counterintuitive. A possible reason is that juices used in the studies were derived from different sources and thus had different polyphenolic content. Sumner's group used a commercial pomegranate juice with no details of the polyphenolic composition, while Aviram's group produced an in-house concentrated form of pomegranate juice, which had been chemically analysed. The differences in the health status of the participants in the studies and the length of dietary intervention may also explain these discrepancies.

A study investigating the effect of consuming $150 \mathrm{~g} / \mathrm{d}$ of a combination of berries (bilberries, lingonberries, blackcurrant puree, strawberry puree and raspberry juice) for $56 \mathrm{~d}$ in seventy-two participants with CVD risk factors reported a significantly lower BP in the highest tertile subgroup ${ }^{(29)}$. The only other study reporting a significant effect of fruits on BP was a study investigating the effect of a chokeberry extract ( $255 \mathrm{mg} / \mathrm{d}$ for $42 \mathrm{~d}$ ) in forty-four myocardial infarction survivors taking statins. It was reported that SBP and diastolic BP were significantly reduced ${ }^{(44)}$. In all other studies, investigating the consumption of cranberry juice or extract, marula juice, blond and red grapefruit juice, no significant effects on BP were reported ${ }^{(45-47)}$.

The type and quantity of polyphenols in the fruits tested were of paramount importance to the bioactive effect. It is interesting to note that chokeberries, which originate from an American native bush (Aronia melanocarpa), contain five- to ten-fold higher anthocyanin and polyphenol levels than cranberry and were reported to have similar anti-oxidative properties ${ }^{(48)}$. It was also reported that chokeberry had the highest dry weight concentrations of phenolic compounds among the berry fruits and contained polyphenols analogous to those found in pomegranate fruit ${ }^{(43)}$. This reported difference in polyphenol content of chokeberries than that of cranberries could be a valid contributing factor for why chokeberries, but not cranberries, were effective in reducing BP despite containing similar classes of flavonoids. From the limited evidence to date, pomegranate and berries are the polyphenol-rich fruits reported to have significant effects on BP.

\section{Vascular function}

Endothelial dysfunction is determined by two clinical measurements: enhanced and maintained endothelial activation and impaired endothelium-dependent vasodilation. Endothelial activation is recognised by the increased concentrations of substances that are shed and released into the plasma from the activated endothelium and macrophage ${ }^{(49)}$. They include mediators of vascular tone, and fibrinolytic, coagulation and pro-inflammatory factors. Impairment of endothelium-dependent vasodilation can be detected using several invasive and non-invasive methods. Non-invasive techniques of measuring endothelium-dependent vasodilatation $^{(50)}$ include flow-mediated dilation, laser doppler imaging with ionotophoresis, pulse wave velocity/analysis, digital volume pulse, sophisticated electron spin spectroscopy and carotid intima-media thickness (CIMT). Many of these techniques require specialised technical expertise and expensive equipment for assessment, making measurement of endothelium-dependent vasodilatation challenging ${ }^{(9)}$.
The effects of fruit polyphenols on endothelium-dependent vasodilation in human intervention studies are shown in Table 3. The application of vascular function determination as a marker of CVD risk is relatively new, and it is unsurprising that there are only limited studies investigating the impact of fruit polyphenols on this CVD risk marker. To date, the human studies examining fruit polyphenols and endothelium-dependent vasodilatation have focussed on two main fruit juices: purple grape juice and pomegranate juice, although the impact of grape seed extract and fruit and vegetable puree drinks has also been investigated. The observations from studies investigating fruit polyphenols and vascular function generally support a beneficial effect of these compounds on measures of vascular reactivity or CIMT. With the exception of the study by Stein et al. ${ }^{(51)}$, the intervention studies on fruit polyphenols and endothelium-dependent vasodilatation were of chronic study design and for relatively long-time periods ranging from 6 weeks to 3 years. It is also of note that the majority of the studies involved subjects with clinical signs of CVD in whom changes may be more marked. For example, in the case of CIMT, evidence of benefits was not observed when baseline CIMT was low ${ }^{(52)}$. This may explain the lack of change in the CIMT after a year of consuming $250 \mathrm{ml} / \mathrm{d}$ of pomegranate juice in 289 subjects with one CVD risk factor in Davidson et al.'s study ${ }^{(52)}$. This is despite ingesting higher dosage of pomegranate juice than participants in Aviram's 2004 study $^{(53)}$, where significant improvement in CIMT was reported in patients with asymptomatic severe carotid stenosis. A subgroup analysis in Davidson's study revealed that improvement in anterior and/or composite CIMT was only found in subjects who had the greatest risk factors (i.e. the top tertiles for baseline TAG, total cholesterol:HDL-cholesterol ratio, TAG:HDL-cholesterol ratio, apo-B100 and lowest tertile for HDL-cholesterol). The confounding effects of including subjects with clinical CVD are the potential impact of medication usage on outcome measures. The methodology of the study is further weakened if a control group is not included ${ }^{(51,54)}$, and it is not possible to compare the results from these types of data with controlled studies.

The importance of combining different polyphenolic compounds on endothelial outcome measures was highlighted by Clifton $^{(55)}$. Individually, grape seed extract and quercetin were reported to have anti-atherogenic properties in animal $^{(56,57)}$ and in vitro studies ${ }^{(56)}$, respectively. When combined, grape seed extract improved flow-mediated dilation by an absolute $1.1 \%$ when compared with control in a human study, while the addition of quercetin appeared to nullify the positive effect on endothelial function completely.

Contrary to human studies, there exists a wealth of evidence on the vasorelaxant properties of polyphenols from grape and grape products in the large conductance (aorta) and smaller resistance (mesenteric) vessels of rats ex vivo ${ }^{(24)}$. Similar studies were also performed on isolated vessels from human subjects and various animals using plant polyphenols from a variety of sources, such as wines, tea, hawthorn and maritime pine bark ${ }^{(58)}$. These studies reported that the plant polyphenols produce endothelium-dependent vasorelaxation, which was associated with increased NO availability (a potent vasodilator). It is beyond the scope of this review to discuss possible mechanisms, but Stoclet et al. ${ }^{(58)}$ provide a good review. 
Table 3. Effects of fruit polyphenols on vascular function (endothelium-dependent vasodilation) in human intervention studies*

\begin{tabular}{|c|c|c|c|c|c|c|c|c|}
\hline References & Study design & Substance given & Principal polyphenol† & Dose/d & Days & Subjects & Biomarkers & Effects $\ddagger$ \\
\hline $\begin{array}{l}\text { Stein } \\
\quad \text { et al. }\end{array}$ & $\begin{array}{l}\text { Chronic, single } \\
\text { arm, no control }\end{array}$ & $\begin{array}{l}\text { Purple } \\
\text { grape juice } \\
\text { (Welch's 100\% } \\
\text { Concord grape) }\end{array}$ & $\begin{array}{c}\text { Cinnamic acids, } \\
\text { anthocyanins }\end{array}$ & $4 \mathrm{ml} / \mathrm{kg}$ twice daily & 14 & $\begin{array}{l}\text { Fifteen with } \\
\text { angiographically } \\
\text { documented CHD }\end{array}$ & FMD & $\uparrow(4 \cdot 2 \%)$ \\
\hline $\begin{array}{l}\text { Chou } \\
\quad \text { et al. }\end{array}$ & $\begin{array}{l}\text { Chronic, } \\
\text { single arm, } \\
\text { no control, } \\
\text { dose response }\end{array}$ & $\begin{array}{l}\text { Purple grape } \\
\text { juice (Welch's } \\
100 \% \text { Concord } \\
\text { grape) }\end{array}$ & $\begin{array}{l}\text { Cinnamic acids, } \\
\text { anthocyanins }\end{array}$ & $\begin{array}{l}8 \mathrm{ml} / \mathrm{kg} \text { twice } \\
\text { daily for } n 11 \\
\text { (high dose) } \\
4 \mathrm{ml} / \mathrm{kg} \text { once } \\
\text { daily for next } \\
n 11 \text { (low dose) }\end{array}$ & 28 & $\begin{array}{l}\text { Twenty-two with } \\
\text { angiographically } \\
\text { documented CHD }\end{array}$ & FMD & $\begin{array}{l}\uparrow(1.6 \%) \text { for both } \\
\text { groups combined }\end{array}$ \\
\hline Clifton ${ }^{(55)}$ & $\begin{array}{l}\text { Chronic, } \\
\text { controlled } \\
\text { crossover }\end{array}$ & $\begin{array}{l}\text { GSD and } \\
\text { quercetin }\end{array}$ & Proanthocyanidins & $\begin{array}{l}2 \mathrm{~g} \text { GSE or } \\
\text { with } 1 \mathrm{~g} \text { quercetin }\end{array}$ & 28 & $\begin{array}{l}\text { Thirty-six with } \\
\text { above average } \\
\text { vascular risk }\end{array}$ & $\begin{array}{l}\text { FMD (GSD alone) } \\
\text { FMD (with quercetin) } \\
\text { PWA }\end{array}$ & $\begin{array}{l}\uparrow(1.1 \%) \\
\text { Nullify FMD effect } \\
\leftrightarrow\end{array}$ \\
\hline $\begin{array}{l}\text { Aviram } \\
\quad \text { et al. }\end{array}$ & $\begin{array}{l}\text { Chronic, } \\
\text { controlled } \\
\text { parallel }\end{array}$ & $\begin{array}{l}\text { Pomegranate } \\
\text { juice }\end{array}$ & $\begin{array}{l}\text { Tannins, } \\
\text { anthocyanins }\end{array}$ & $50 \mathrm{ml}$ & $\begin{array}{l}1-3 \\
\text { years }\end{array}$ & $\begin{array}{l}\text { Nineteen } \\
\text { patients with } \\
\text { asymptomatic } \\
\text { severe carotid } \\
\text { artery stenosis }\end{array}$ & $\begin{array}{l}\text { CIMT (after } 3 \text { years) } \\
\text { CIMT (after } 1 \text { year) }\end{array}$ & $\begin{array}{l}\downarrow \text { (30\%) } \\
\text { No further benefits }\end{array}$ \\
\hline $\begin{array}{l}\text { Sumner } \\
\text { et al. }\end{array}$ & $\begin{array}{l}\text { Chronic, } \\
\text { controlled } \\
\text { parallel }\end{array}$ & $\begin{array}{l}\text { Pomegranate } \\
\text { juice }\end{array}$ & $\begin{array}{l}\text { Tannins, } \\
\text { anthocyanins }\end{array}$ & $240 \mathrm{ml}$ & 90 & $\begin{array}{l}\text { Forty-five with } \\
\text { ischaemic } \\
\text { coronary disease } \\
\text { and myocardial } \\
\text { ischaemia }\end{array}$ & Myocardial perfusion & $\begin{array}{l}\text { Improved (17\%) in } \\
\text { treatment group } \\
\text { and worsened } \\
(18 \%) \text { in ctrl grp }\end{array}$ \\
\hline \multirow[t]{4}{*}{$\begin{array}{l}\text { Davidson } \\
\text { et al. }{ }^{(52)} \\
\text { (Aviram's } \\
\text { group) }\end{array}$} & $\begin{array}{l}\text { Chronic, } \\
\text { controlled } \\
\text { parallel }\end{array}$ & $\begin{array}{l}\text { Pomegranate } \\
\text { juice }\end{array}$ & $\begin{array}{l}\text { Tannins, } \\
\text { anthocyanins }\end{array}$ & $240 \mathrm{ml}$ & $\stackrel{18}{\text { months }}$ & $\begin{array}{l}289 \text { subjects } \\
\text { with one } \\
\text { or more coronary } \\
\text { heart disease }\end{array}$ & $\begin{array}{r}\text { Composite CIMT } \\
\text { (at } 12 \text { months) } \\
\text { Composite CIMT } \\
\text { (at } 18 \text { months) }\end{array}$ & $\begin{array}{l}\text { Lower value than } \\
\text { ctrl grp§ } \\
\leftrightarrow\end{array}$ \\
\hline & & & & & & risk factor & $\begin{array}{l}\text { Posterior wall CIMT } \\
\text { For groups at top } \\
\text { tertiles\| }\end{array}$ & $\leftrightarrow$ \\
\hline & & & & & & & Anterior CIMT & $\begin{array}{l}\text { Lower values than } \\
\text { ctrl grp§ }\end{array}$ \\
\hline & & & & & & & Composite CIMT & $\begin{array}{l}\text { Lower values than } \\
\text { ctrl grp§ }\end{array}$ \\
\hline \multirow[t]{2}{*}{$\begin{array}{l}\text { George } \\
\quad \text { et al. }\end{array}$} & $\begin{array}{l}\text { Chronic, } \\
\text { controlled } \\
\text { crossover }\end{array}$ & $\begin{array}{l}\text { Fruits and vegetables } \\
\text { puree-based drinks } \\
\text { (Vie shots, Unilever } \\
\text { Bestfoods) }\end{array}$ & & $2 \times 100 \mathrm{ml}$ & 42 & Thirty-nine healthy & $\begin{array}{l}\text { LDI (endothelium- } \\
\text { dependent } \\
\text { vasodilation) }\end{array}$ & $\begin{array}{l}\uparrow \text { but not statistically } \\
\text { significant§ }\end{array}$ \\
\hline & $\begin{array}{l}\text { Acute, } \\
\text { controlled } \\
\text { crossover }\end{array}$ & $\begin{array}{l}\text { Fruits and vegetables } \\
\text { puree-based drinks } \\
\text { (Vie shots, Unilever } \\
\text { Bestfoods) }\end{array}$ & & $400 \mathrm{ml}$ & ${ }^{1}$ Postprandial & Twenty-four healthy & $\begin{array}{l}\text { LDI (endothelium- } \\
\text { dependent } \\
\text { vasodilation) }\end{array}$ & $\begin{array}{l}\uparrow \text { for GG genotype } \\
\text { only } \S\end{array}$ \\
\hline
\end{tabular}

FMD, flow-mediated vasodilation; GSD, grape seed extract; PWA, pulse wave analysis; CIMT, carotid intima-media thickness; ctrl grp, control group; LDI, laser Doppler iontophoresis.

* Table is arranged by similar fruit type, followed by year in ascending order for fruits investigated by a single study.

† Only the top two polyphenols with the highest concentrations reported in the reference papers are listed.

$\mp \uparrow$ refers to increase; $\downarrow$ refers to decrease; $\leftrightarrow$ refers to no change; unless otherwise stated, (\%) refers to changes from baseline when test substance given.

$\S$ Refer to reference papers for details of data.

|| Refers to subjects in the top tertiles for baseline TAG, total cholesterol:HDL-cholesterol ratio, TAG:HDL-cholesterol ratio and apo-B100. 
In vitro studies using blackberry ${ }^{(59)}$ and elderberry ${ }^{(60)}$ extract on human umbilical vein endothelial cells and an ex vivo study, where rats were fed a diet rich in wild blueberries, have reported protective effects of endothelial dysfunction and vascular failure. It would seem prudent to further investigate the effects of these berries on endothelium-dependent vasodilation in human subjects.

\section{Blood lipids}

Among the four risk factors described in this review, blood lipids were the most frequently determined factor in the human intervention trials investigating the impact of fruit polyphenols on CVD risk markers. The effects of fruit polyphenols on CVD risk markers in these human intervention studies are shown in Table 4. Interestingly, fruits rich in anthocyanins and procyanindins, which have been associated with beneficial effects on platelet function, BP and vascular function, appear to have little or no impact on human blood lipids ${ }^{(25,27,43,47,54,61)}$. In contrast, fruits rich in flavanones appear to have some impact on blood lipids. Those found to have hypocholesterolaemic effects include marula, grapefruit and oranges. Consumption of $200 \mathrm{ml}$ marula juice for $21 \mathrm{~d}$ resulted in a favourable lipoprotein profile with significant reductions in total and LDL-cholesterol and TAG and a concomitant increase in HDL-cholesterol ${ }^{(46)}$. Consumption of one grapefruit (red or blond) beneficially influenced total and LDL-cholesterol and TAG, with red grapefruit being more effective than blond grapefruit ${ }^{(45)}$. In the two studies that investigated orange juice, it appeared to favourably improve LDL:HDL-cholesterol ratio, although a significant hypertriacylglcyerolaemic effect was also reported $^{(62,63)}$. It is possible that responses to blood lipids could be influenced by the individual's health status. Significant reductions in plasma lipids were observed in studies investigating hypercholesterolaemic subjects ${ }^{(45,63)}$, whereas little or no effect was reported in healthy subjects $^{(25,27,47,64)}$.

\section{Discussion}

Current limited evidence appeared to suggest that fruits containing relatively high concentrations of flavonols, anthocyanins and procyanindins, such as pomegranate, purple grapes and berries, were more effective at reducing CVD risk, particularly with respect to anti-hypertensive effects, inhibition of platelet aggregation and increasing endothelial-dependent vasodilation than other fruits investigated. Flavanone-rich fruits, such as oranges and grapefruits, on the other hand, were reported to have hypocholesterolaemic effects, with little impact on other risk factors being examined. However, it must be noted that evidence was limited, mostly inconsistent and often inconclusive.

A key difficulty in drawing clear conclusions from the current evidence is the inconsistency in study design: studies were mainly of chronic design, with only a small number investigating the acute impact of fruit polyphenols ${ }^{(28,38,45,65)}$; the more robustly designed studies included control arms and data from those that were not controlled $(25,27,46,47,51,62,63,66)$ were difficult to interpret and impossible to compare with the controlled studies; polyphenols were mainly consumed in the form of fruit juices or fruits, but a small number of studies provided polyphenols in the form of supplements $^{(31,38,43,55)}$ negating direct comparisons; the duration of study period ranged from weeks to months between studies, and the dose of polyphenols investigated was not consistent between studies. In addition, the types of subjects recruited differed, with some studies using healthy subjects, while others recruited subjects at risk of CVD or had CVD $^{(29,43,45,51-53,61,63,66,67)}$. It appears that observed effects were generally more marked in subjects at higher CVD risk. The heterogeneity in the design of the current studies, combined with the limited number of studies conducted to date, makes drawing conclusions problematic.

It is important that subject compliance is considered in any intervention study as this could impact significantly on the outcome measures, particularly if compliance was low. Differences in the degree of dietary compliance could account for inconsistencies in the results obtained from the various studies. In half of the studies included in this review, compliance was not assessed, with only four studies providing data on the extent of compliance ${ }^{(29,30,54,61)}$. Methods of assessing compliance included diet diaries, log books, frequent interviews by the researchers and biomarkers. For future studies, consideration must be given to standardising analytical methodology to allow valid comparison to be made between studies. This is particularly important in the quantification of specific and total polyphenols in fruits. Differences in the concentration of the bioactive flavonoid components within the fruits ingested in the various studies have been consistently highlighted as a possible factor influencing the variable effects of similar types of fruits/fruit juice. In some studies, details of the polyphenol content of the fruits investigated were omitted, negating comparison of studies.

Besides vascular function studies, which were carried out for longer periods, many studies reviewed were for relatively short intervention periods and of low power. Large, wellpowered, long-term human dietary intervention studies investigating a wider range of fruits would be required to improve the credibility of findings and confirm current observations. In addition, investigations into the postprandial effects of acute ingestion of foods are limited. There is a need for combinations of acute and chronic studies to resolve issues concerning bioavailability of polyphenol compounds. In addition, investigating into the impact of nutrient-gene interaction would help to further elucidate the large interindividual variation in response. George et al. ${ }^{(65)}$ observed that acute consumption of fruit and vegetable puree drinks induced improvements in endothelium-dependent vasodilation determined by laser doppler imaging with iontophoresis in individuals with the GG variant of the eNOS gene but not in those with the GT variant.

It was reported that there was an observed greater improvement in anti-platelet activity and endothelium-dependent vasodilation by the synergistic effects of combining polyphenolic compounds. This could imply that whole fruits or fruit juice, rather than isolated polyphenols, would be more effective in reducing CVD risk, although this will require confirmation. Dose-response studies are thus recommended to help elucidate the actual quantity of polyphenols or combination of polyphenols required for effective results. 
WS British Journal of Nutrition

Table 4. Effects of fruit polyphenols on blood lipids in human intervention studies*

\begin{tabular}{|c|c|c|c|c|c|c|c|c|}
\hline References & Study design & Substance given & Principal polyphenol† & Dose/d & Days & Subjects & Biomarkers & Effects $\ddagger$ \\
\hline $\begin{array}{l}\text { Aviram } \\
\quad \text { et al. }\end{array}$ & $\begin{array}{l}\text { Chronic, } \\
\text { single arm, } \\
\text { no control }\end{array}$ & $\begin{array}{l}\text { Pomegranate } \\
\text { juice }\end{array}$ & $\begin{array}{l}\text { Tannins, } \\
\text { anthocyanins }\end{array}$ & $50 \mathrm{ml}$ & 14 & Thirteen healthy & $\begin{array}{l}\text { Total cholesterol, } \\
\text { LDL-chol, } \\
\text { VLDL-chol, } \\
\text { HDL-chol, } \\
\text { TAG }\end{array}$ & $\begin{array}{l}\stackrel{\leftrightarrow}{\leftrightarrow} \\
\stackrel{\leftrightarrow}{\leftrightarrow} \\
\leftrightarrow\end{array}$ \\
\hline $\begin{array}{l}\text { Aviram } \\
\quad \text { et al. }\end{array}$ & $\begin{array}{l}\text { Chronic, } \\
\text { controlled } \\
\text { parallel }\end{array}$ & $\begin{array}{l}\text { Pomegranate } \\
\text { juice }\end{array}$ & $\begin{array}{l}\text { Tannins, } \\
\text { anthocyanins }\end{array}$ & $50 \mathrm{ml}$ & $\begin{array}{l}1-3 \\
\text { years }\end{array}$ & $\begin{array}{l}\text { Nineteen patients } \\
\text { with asymptomatic } \\
\text { severe carotid artery } \\
\text { stenosis }\end{array}$ & $\begin{array}{l}\text { HDL-chol, } \\
\text { LDL-chol }\end{array}$ & $\overleftrightarrow{\leftrightarrow}$ \\
\hline $\begin{array}{l}\text { Sumner } \\
\text { et al. }{ }^{(61)}\end{array}$ & $\begin{array}{l}\text { Chronic, } \\
\text { controlled } \\
\text { parallel }\end{array}$ & $\begin{array}{l}\text { Pomegranate } \\
\text { juice }\end{array}$ & $\begin{array}{l}\text { Tannins, } \\
\text { anthocyanins }\end{array}$ & $240 \mathrm{ml}$ & 90 & $\begin{array}{l}\text { Forty-five with ischaemic } \\
\text { coronary disease and } \\
\text { myocardial ischemia }\end{array}$ & $\begin{array}{l}\text { Total cholesterol, } \\
\text { LDL-chol, } \\
\text { HDL-chol, } \\
\text { TAG }\end{array}$ & $\begin{array}{l}\leftrightarrow \\
\leftrightarrow \\
\leftrightarrow \\
\leftrightarrow\end{array}$ \\
\hline $\begin{array}{l}\text { Davidson } \\
\text { et al. }{ }^{(52)} \\
\text { (Aviram's } \\
\text { group) }\end{array}$ & $\begin{array}{l}\text { Chronic, } \\
\text { controlled } \\
\text { parallel }\end{array}$ & $\begin{array}{l}\text { Pomegranate } \\
\text { juice }\end{array}$ & $\begin{array}{l}\text { Tannins, } \\
\text { anthocyanins }\end{array}$ & $240 \mathrm{ml}$ & $\begin{array}{l}18 \\
\text { months }\end{array}$ & $\begin{array}{l}289 \text { subjects with one or } \\
\text { more } \mathrm{CHD} \text { risk factor }\end{array}$ & $\begin{array}{l}\text { Fasting } \\
\text { apo-B100 }\end{array}$ & $\begin{array}{l}\leftrightarrow 4 \\
44 \% \text { less in } \\
\text { treatment } \\
\text { group than } \\
\text { ctrl grp }\end{array}$ \\
\hline $\begin{array}{l}\text { Chou } \\
\quad \text { et al. }\end{array}$ & $\begin{array}{l}\text { Chronic, } \\
\text { single arm, } \\
\text { no control, } \\
\text { dose response }\end{array}$ & $\begin{array}{l}\text { Purple } \\
\text { grape juice } \\
\text { (Welch's 100\% } \\
\text { Concord grape) }\end{array}$ & $\begin{array}{l}\text { Cinnamic } \\
\text { acids, } \\
\text { anthocyanins }\end{array}$ & $\begin{array}{l}8 \mathrm{ml} / \mathrm{kg} \text { twice } \\
\text { daily for } n 11 \\
\text { (high dose) } \\
4 \text { ml/kg once daily } \\
\text { for next } n 11 \\
\text { (low dose) }\end{array}$ & 28 & $\begin{array}{l}\text { Twenty-two with } \\
\text { angiographically } \\
\text { documented CHD }\end{array}$ & $\begin{array}{l}\text { Total cholesterol, } \\
\text { LDL-chol, } \\
\text { HDL-chol, } \\
\text { TAG }\end{array}$ & $\begin{array}{l}\leftrightarrow \\
\leftrightarrow \\
\leftrightarrow\end{array}$ \\
\hline $\begin{array}{l}\text { Freedman } \\
\quad \text { et al. }\end{array}$ & $\begin{array}{l}\text { Chronic, } \\
\text { single arm, } \\
\text { no control }\end{array}$ & $\begin{array}{l}\text { Purple grape } \\
\text { juice (Welch's) }\end{array}$ & $\begin{array}{l}\text { Cinnamic acids, } \\
\text { anthocyanins }\end{array}$ & $7 \mathrm{ml} / \mathrm{kg}$ body wt & 14 & Twenty healthy & $\begin{array}{l}\text { Plasma total } \\
\text { cholesterol }\end{array}$ & $\leftrightarrow$ \\
\hline Clifton $^{(55)}$ & $\begin{array}{l}\text { Chronic, } \\
\text { controlled } \\
\text { crossover }\end{array}$ & $\begin{array}{l}\text { GSD and } \\
\text { quercetin }\end{array}$ & Proanthocyanidins & $\begin{array}{l}2 \mathrm{~g} \text { GSE or with } \\
1 \mathrm{~g} \text { quercetin }\end{array}$ & 28 & $\begin{array}{l}\text { Thirty-six with } \\
\text { above average } \\
\text { vascular risk }\end{array}$ & $\begin{array}{l}\text { Total cholesterol, } \\
\text { LDL-chol, } \\
\text { HDL-chol, } \\
\text { TAG }\end{array}$ & $\begin{array}{l}\leftrightarrow \\
\leftrightarrow \\
\leftrightarrow \\
\leftrightarrow\end{array}$ \\
\hline Ruel et al..(47) & $\begin{array}{l}\text { Chronic, } \\
\text { single arm, } \\
\text { no control }\end{array}$ & $\begin{array}{l}\text { Cranberry } \\
\text { juice } \\
\text { (Ocean Spray's) }\end{array}$ & & $7 \mathrm{ml} / \mathrm{kg}$ body wt & 14 & $\begin{array}{l}\text { Twenty-one } \\
\text { healthy }\end{array}$ & $\begin{array}{l}\text { Total cholesterol, } \\
\text { LDL-chol, } \\
\text { HDL-chol, } \\
\text { TAG, } \\
\text { apo-B100 }\end{array}$ & $\begin{array}{l}\stackrel{\leftrightarrow}{\leftrightarrow} \\
\leftrightarrow \\
\leftrightarrow\end{array}$ \\
\hline Duthie et al. ${ }^{(64)}$ & $\begin{array}{l}\text { Chronic, } \\
\text { controlled } \\
\text { crossover }\end{array}$ & $\begin{array}{l}\text { Cranberry } \\
\text { juice }\end{array}$ & $\begin{array}{c}\text { Anthocyanins } \\
\text { Catechins }\end{array}$ & $750 \mathrm{ml}$ & 14 & Twenty healthy & $\begin{array}{l}\text { Total cholesterol, } \\
\text { LDL-chol, } \\
\text { HDL-chol, } \\
\text { TAG }\end{array}$ & $\begin{array}{l}\leftrightarrow \\
\leftrightarrow \\
\leftrightarrow \\
\leftrightarrow\end{array}$ \\
\hline $\begin{array}{l}\text { Kurowska } \\
\text { et al. }{ }^{(63)}\end{array}$ & $\begin{array}{l}\text { Chronic, } \\
\text { single arm, } \\
\text { dose } \\
\text { response }\end{array}$ & $\begin{array}{l}\text { Orange } \\
\text { juice }\end{array}$ & Flavonoids & $250 / 500 / 750 \mathrm{ml}$ & 28 & $\begin{array}{l}\text { Twenty-five } \\
\text { subjects with } \\
\text { moderate } \\
\text { hypercholesterolaemia }\end{array}$ & $\begin{array}{l}\text { Total cholesterol, } \\
\text { LDL-chol } \\
\text { For } 750 \mathrm{ml} \text { only } \\
\text { HDL-chol } \\
\text { LDL:HDL-chol ratio } \\
\text { TAG } \\
\text { apo-B } \\
\text { apo-A-I }\end{array}$ & $\begin{array}{l}\leftrightarrow(21 \%) \\
\uparrow(16 \%) \\
\downarrow(16 \%) \\
\uparrow(30 \%) \\
\leftrightarrow \\
\leftrightarrow \\
\leftrightarrow \\
\leftrightarrow\end{array}$ \\
\hline
\end{tabular}


WS British Journal of Nutrition

Table 4. Continued

\begin{tabular}{|c|c|c|c|c|c|c|c|c|}
\hline References & Study design & Substance given & Principal polyphenol† & Dose/d & Days & Subjects & Biomarkers & Effectsł \\
\hline $\begin{array}{l}\text { Franke } \\
\quad \text { et al. }\end{array}$ & $\begin{array}{l}\text { Chronic, } \\
\text { single arm, } \\
\text { no control }\end{array}$ & $\begin{array}{l}\text { Orange juice } \\
\text { (Tropicana) }\end{array}$ & $\begin{array}{l}\text { Flavanones, } \\
\text { carotenoids }\end{array}$ & $682 \mathrm{ml}$ daily & 21 & Thirteen healthy & $\begin{array}{l}\text { TAG } \\
\text { Total cholesterol, } \\
\text { HDL-chol, } \\
\text { LDL-chol } \\
\text { LDL:HDL-chol ratio }\end{array}$ & $\begin{array}{l}\uparrow(26 \%) \\
\leftrightarrow \\
\leftrightarrow \\
\leftrightarrow \\
\downarrow \text { but not } \\
\quad \text { statistically } \\
\text { significant§ }\end{array}$ \\
\hline $\begin{array}{l}\text { Eccleston } \\
\text { et al. }{ }^{(30)}\end{array}$ & $\begin{array}{l}\text { Chronic, } \\
\text { controlled } \\
\text { crossover }\end{array}$ & $\begin{array}{l}\text { Sea buckthorn } \\
\text { juice }\end{array}$ & Isorhamnetin-rutinoside & $300 \mathrm{ml}$ daily & 56 & Twenty healthy & $\begin{array}{l}\text { HDL-chol } \\
\text { TAG } \\
\text { Total cholesterol } \\
\text { LDL-chol }\end{array}$ & $\begin{array}{l}\uparrow(20 \%) \\
\uparrow(17 \%) \\
\leftrightarrow \\
\leftrightarrow\end{array}$ \\
\hline $\begin{array}{l}\text { Gorinstein } \\
\quad \text { et al. }{ }^{(43)}\end{array}$ & $\begin{array}{l}\text { Chronic, } \\
\text { controlled } \\
\text { parallel }\end{array}$ & $\begin{array}{l}\mathrm{R} \text { or } \mathrm{B} \\
\quad \text { grapefruit }\end{array}$ & $\begin{array}{l}\text { Flavonoids, } \\
\text { anthocyanins }\end{array}$ & One fruit & 30 & $\begin{array}{l}\text { Fifty-seven } \\
\text { hyperlipidaemics } \\
\text { after coronary } \\
\text { bypass surgery }\end{array}$ & $\begin{array}{l}\text { Total cholesterol in } \\
\text { R, B grps } \\
\text { LDL-chol in R, B } \\
\text { grps } \\
\text { TAG in R, B grps }\end{array}$ & $\begin{array}{l}\downarrow(15 \cdot 5,7 \cdot 6 \%) \\
\downarrow(20 \cdot 3,10 \cdot 7 \%) \\
\downarrow(17 \cdot 2,5 \cdot 6 \%)\end{array}$ \\
\hline $\begin{array}{l}\text { Naruszewicz } \\
\quad \text { et al. }\end{array}$ & $\begin{array}{l}\text { Chronic, } \\
\text { controlled } \\
\text { parallel }\end{array}$ & $\begin{array}{l}\text { Chokeberry } \\
\text { flavonoid extract }\end{array}$ & $\begin{array}{l}\text { Anthocyanins, } \\
\text { procyanidins }\end{array}$ & $3 \times 85 \mathrm{mg}$ & 42 & $\begin{array}{l}\text { Forty-four } \\
\text { myocardial } \\
\text { infarction survivors } \\
\text { on statins for } \\
6 \text { months }\end{array}$ & $\begin{array}{l}\text { Total cholesterol, } \\
\text { LDL-chol, } \\
\text { HDL-chol, } \\
\text { TAG }\end{array}$ & $\begin{array}{l}\leftrightarrow \\
\leftrightarrow \\
\leftrightarrow \\
\leftrightarrow\end{array}$ \\
\hline $\begin{array}{l}\text { Borochov-Neori } \\
\quad \text { et al. }{ }^{(46)}\end{array}$ & $\begin{array}{l}\text { Chronic, } \\
\text { single arm, } \\
\text { no control. }\end{array}$ & Marula juice & $\begin{array}{l}\text { Hydrolysable } \\
\text { tannins, } \\
\text { catechins }\end{array}$ & $200 \mathrm{ml}$ & 21 & Ten healthy & $\begin{array}{l}\text { HDL-chol } \\
\text { Total cholesterol } \\
\text { LDL-chol } \\
\text { TAG }\end{array}$ & $\begin{array}{l}\uparrow(10 \%) \\
\downarrow(8 \%) \\
\downarrow(17 \%) \\
\downarrow(7 \%)\end{array}$ \\
\hline Erlund et al. ${ }^{(29)}$ & $\begin{array}{l}\text { Chronic, } \\
\text { controlled } \\
\text { crossover }\end{array}$ & $\begin{array}{l}\text { A combination } \\
\text { of bilberries, } \\
\text { lingonberries, } \\
\text { blackcurrant } \\
\text { and strawberry } \\
\text { puree and } \\
\text { raspberry juice }\end{array}$ & Anthocyanins & $150 \mathrm{~g}$ & 56 & $\begin{array}{l}\text { Seventy-two subjects } \\
\text { with CVD risk factors }\end{array}$ & $\begin{array}{l}\text { Total cholesterol } \\
\text { TAG } \\
\text { HDL-chol }\end{array}$ & $\begin{array}{l}\uparrow \\
\leftrightarrow \\
\uparrow \text { more in } \\
\text { treatment grp } \\
\text { than ctrl grp§ }\end{array}$ \\
\hline \multirow[t]{2}{*}{ George et al..$^{(65)}$} & $\begin{array}{l}\text { Chronic, } \\
\text { controlled } \\
\text { crossover }\end{array}$ & $\begin{array}{l}\text { Fruits and } \\
\text { vegetables } \\
\text { puree-based } \\
\text { drinks (Vie shots, } \\
\text { Unilever } \\
\text { Bestfoods) }\end{array}$ & & $2 \times 100 \mathrm{ml}$ & 42 & Thirty-nine healthy & $\begin{array}{l}\text { TAG, } \\
\text { HDL-chol, } \\
\text { total cholesterol, } \\
\text { NEFA }\end{array}$ & $\begin{array}{l}\leftrightarrow \\
\leftrightarrow \\
\leftrightarrow \\
\leftrightarrow\end{array}$ \\
\hline & $\begin{array}{l}\text { Acute, } \\
\text { controlled } \\
\text { crossover }\end{array}$ & $\begin{array}{l}\text { Fruits and } \\
\text { vegetables } \\
\text { puree-based } \\
\text { drinks (Vie } \\
\text { shots, Unilever } \\
\text { Bestfoods) }\end{array}$ & & $400 \mathrm{ml}$ & 1 & Twenty-four healthy & $\begin{array}{l}\text { TAG, } \\
\text { HDL-chol, } \\
\text { total cholesterol, } \\
\text { NEFA }\end{array}$ & $\begin{array}{l}\stackrel{\leftrightarrow}{\leftrightarrow} \\
\leftrightarrow \\
\leftrightarrow\end{array}$ \\
\hline
\end{tabular}

Chol (e.g. HDL-chol), cholesterol; GSD, grape seed extract; R, red; B, blond; ctrl, control; Grp, group.

Table is arranged by similar fruit type, followed by year in ascending order of fruits investigated by a single study.

Only the top two polyphenols with the highest concentrations reported in the reference papers are listed.

$\uparrow$ refers to increase; $\downarrow$ refers to decrease; $\leftrightarrow$ refers to no change; unless otherwise stated, $(\%)$ refers to changes from baseline when test substance given.

$\S$ Reference papers for details of data. 


\section{Conclusion}

In conclusion, there is some supportive evidence for the beneficial effects of fruit polyphenols on CVD risk. Pomegranate, purple grapes and certain berries were the most frequently investigated fruits and found to be effective in reducing CVD risk, particularly with respect to lowering $\mathrm{BP}$, inhibition of platelet aggregation and increasing vascular function. These fruits contain relatively high concentrations of flavonols, anthocyanins and procyanindins in addition to other nutrients and polyphenols. In contrast, fruits rich in flavanones, such as oranges and grapefruits, appeared to have limited impact on BP, platelet and vascular function, but did have beneficial effects on blood lipid profiles. However, more human intervention studies examining a greater range of fruits are required to confirm these observations.

The literature to date is limited and often inconsistent in study design. Long intervention periods are the key and should be encouraged in future studies. Improvements and standardisation in the methodology for quantifying the polyphenolic content of fruits are the priorities. This will facilitate the comparison of studies and provide valuable information on the types of fruits for further investigations. In future, welldesigned and suitably powered studies are essential for the development of public health nutrition recommendations on fruit consumption. Subjects' compliance to treatment should also be evaluated. Currently, the Food Standards Agency recommends the consumption of five portions of fruits and vegetables daily. There is no guidance on the specific type of fruits and vegetables to consume other than a suggestion of a variety; this is because to date, there is a lack of convincing evidence for their identification. It is therefore of priority to identify fruits (and vegetables), which would significantly contribute to a reduction in CVD and other chronic noncommunicable diseases in order to inform public health recommendations and policy to reduce the present disease burden. Although inconclusive, evidence has alluded to synergistic effects of combinations of polyphenols, which may be more protective against CVD than isolated polyphenols, and that a combination of fruits, in the context of a balanced diet and healthy lifestyle, would help to protect against CVD.

\section{Acknowledgements}

This review was supported by funds from GlaxoSmithKline. The authors have no financial or other relations that could lead to conflict of interest. M. F.-F. C. and R. M. conducted the literature search; M. F.-F. C. and J. A. L. drafted the manuscript; J. A. L. had primary responsibility for final content. All the authors read and approved the final manuscript.

\section{References}

1. Allender S, Scarborough P, Peto V, et al. (2008) European Cardiovascular Disease Statistics 2008, 3rd ed. London: European Heart Network.

2. Joshipura KJ, Hu FB, Manson JE, et al. (2001) The effect of fruit and vegetable intake on risk for coronary heart disease. Ann Intern Med 134, 1106-1114.

3. Dauchet L, Amouyel P \& Dallongeville J (2009) Fruits, vegetables and coronary heart disease. Nat Rev Cardiol 6, 599-608.
4. Scalbert A, Johnson IT \& Saltmarsh M (2005) Polyphenols: antioxidants and beyond. Am J Clin Nutr 81, Suppl. 1, 215S-217S.

5. Arts IC \& Hollman PC (2005) Polyphenols and disease risk in epidemiologic studies. Am J Clin Nutr 81, Suppl. 1, 317S-325S.

6. Hertog MG, Feskens EJ, Hollman PC, et al. (1993) Dietary antioxidant flavonoids and risk of coronary heart disease: the Zutphen Elderly Study. Lancet 342, 1007-1011.

7. Mink PJ, Scrafford CG, Barraj LM, et al. (2007) Flavonoid intake and cardiovascular disease mortality: a prospective study in postmenopausal women. Am J Clin Nutr 85, 895-909.

8. Williamson G \& Manach C (2005) Bioavailability and bioefficacy of polyphenols in humans. II. Review of 93 intervention studies. Am J Clin Nutr 81, Suppl. 1, 243S-255S.

9. Grassi D, Desideri G, Croce G, et al. (2009) Flavonoids, vascular function and cardiovascular protection. Curr Pharm Des 15, 1072-1084.

10. Beecher GR (2003) Overview of dietary flavonoids: nomenclature, occurrence and intake. J Nutr 133, 3248S-3254S.

11. Lusis AJ (2000) Atherosclerosis. Nature 407, 233-241.

12. Ross R (1999) Atherosclerosis - an inflammatory disease. $N$ Engl J Med 340, 115-126.

13. Ezzati M, Lopez AD, Rodgers A, et al. (2002) Selected major risk factors and global and regional burden of disease. Lancet 360, 1347-1360.

14. Williams B, Poulter NR, Brown MJ, et al. (2004) Guidelines for management of hypertension: report of the fourth working party of the British Hypertension Society, 2004-BHS IV. J Hum Hypertens 18, 139-185.

15. Collins R, Peto R, MacMahon S, et al. (1990) Blood pressure, stroke, and coronary heart disease. Part 2: short-term reductions in blood pressure: overview of randomised drug trials in their epidemiological context. Lancet 335, 827-838.

16. Whelton PK, He J, Appel LJ, et al. (2002) Primary prevention of hypertension: clinical and public health advisory from The National High Blood Pressure Education Program. JAMA 288, 1882-1888.

17. Aviram M (2007) Hyperlipidaemia and cardiovascular disease. Curr Opin Lipidol 18, 473-475.

18. Yusuf S, Hawken S, Ounpuu S, et al. (2004) Effect of potentially modifiable risk factors associated with myocardial infarction in 52 countries (the INTERHEART study): case-control study. Lancet 364, 937-952.

19. Vita JA \& Keaney JF Jr (2002) Endothelial function: a barometer for cardiovascular risk? Circulation 106, 640-642.

20. Halcox JP, Donald AE, Ellins E, et al. (2009) Endothelial function predicts progression of carotid intima-media thickness. Circulation 119, 1005-1012.

21. Vita JA (2005) Polyphenols and cardiovascular disease: effects on endothelial and platelet function. Am J Clin Nutr 81, Suppl. 1, 292S-297S.

22. Dangour AD, Dodhia SK, Hayter A, et al. (2009) Nutritional quality of organic foods: a systematic review. Am J Clin Nutr 90, 680-685.

23. Mukamal KJ \& Rimm EB (2001) Alcohol's effects on the risk for coronary heart disease. Alcohol Res Health 25, 255-261.

24. Leifert WR \& Abeywardena MY (2008) Cardioprotective actions of grape polyphenols. Nutr Res 28, 729-737.

25. Freedman JE, Parker C 3rd, Li L, et al. (2001) Select flavonoids and whole juice from purple grapes inhibit platelet function and enhance nitric oxide release. Circulation 103, 2792-2798.

26. Keevil JG, Osman HE, Reed JD, et al. (2000) Grape juice, but not orange juice or grapefruit juice, inhibits human platelet aggregation. J Nutr 130, 53-56.

27. Aviram M, Dornfeld L, Rosenblat M, et al. (2000) Pomegranate juice consumption reduces oxidative stress, atherogenic modifications to LDL, and platelet aggregation: studies in humans and in atherosclerotic apolipoprotein E-deficient mice. Am J Clin Nutr 71, 1062-1076. 
28. Polagruto JA, Gross HB, Kamangar F, et al. (2007) Platelet reactivity in male smokers following the acute consumption of a flavanol-rich grapeseed extract. J Med Food 10, 725-730.

29. Erlund I, Koli R, Alfthan G, et al. (2008) Favorable effects of berry consumption on platelet function, blood pressure, and HDL cholesterol. Am J Clin Nutr 87, 323-331.

30. Eccleston C, Baoru Y, Tahvonen R, et al. (2002) Effects of an antioxidant-rich juice (sea buckthorn) on risk factors for coronary heart disease in humans. J Nutr Biochem 13, 346-354.

31. Conquer JA, Maiani G, Azzini E, et al. (1998) Supplementation with quercetin markedly increases plasma quercetin concentration without effect on selected risk factors for heart disease in healthy subjects. $J$ Nutr 128, 593-597.

32. Janssen K, Mensink RP, Cox FJ, et al. (1998) Effects of the flavonoids quercetin and apigenin on hemostasis in healthy volunteers: results from an in vitro and a dietary supplement study. Am J Clin Nutr 67, 255-262.

33. Rechner AR \& Kroner C (2005) Anthocyanins and colonic metabolites of dietary polyphenols inhibit platelet function. Thromb Res 116, 327-334.

34. Shanmuganayagam D, Beahm MR, Osman HE, et al. (2002) Grape seed and grape skin extracts elicit a greater antiplatelet effect when used in combination than when used individually in dogs and humans. $J$ Nutr 132, 3592-3598.

35. Landolfi R, Mower RL \& Steiner M (1984) Modification of platelet function and arachidonic acid metabolism by bioflavonoids. Structure-activity relations. Biochem Pharmacol 33, 1525-1530.

36. Pace-Asciak CR, Rounova O, Hahn SE, et al. (1996) Wines and grape juices as modulators of platelet aggregation in healthy subjects. Clin Chim Acta 246, 163-182.

37. Freese R, Vaarala O, Turpeinen AM, et al. (2004) No difference in platelet activation or inflammation markers after diets rich or poor in vegetables, berries and apple in healthy subjects. Eur $J$ Nutr 43, 175-182.

38. Hubbard GP, Wolffram S, Lovegrove JA, et al. (2004) Ingestion of quercetin inhibits platelet aggregation and essential components of the collagen-stimulated platelet activation pathway in humans. J Thromb Haemost 2, 2138-2145.

39. Hubbard GP, Wolffram S, de Vos R, et al. (2006) Ingestion of onion soup high in quercetin inhibits platelet aggregation and essential components of the collagen-stimulated platelet activation pathway in man: a pilot study. Br J Nutr 96, 482-488.

40. Huang HY, Huang JJ, Tso TK, et al. (2004) Antioxidant and angiotension-converting enzyme inhibition capacities of various parts of Benincasa hispida (wax gourd). Nahrung 48, 230-233.

41. Moline J, Bukharovich IF, Wolff MS, et al. (2000) Dietary flavonoids and hypertension: is there a link? Med Hypotheses 55, 306-309.

42. Mennen LI, Sapinho D, de Bree A, et al. (2004) Consumption of foods rich in flavonoids is related to a decreased cardiovascular risk in apparently healthy French women. J Nutr 134, 923-926.

43. Gorinstein S, Caspi A, Libman I, et al. (2006) Red grapefruit positively influences serum triglyceride level in patients suffering from coronary atherosclerosis: studies in vitro and in humans. J Agric Food Chem 54, 1887-1892.

44. Naruszewicz M, Laniewska I, Millo B, et al. (2007) Combination therapy of statin with flavonoids rich extract from chokeberry fruits enhanced reduction in cardiovascular risk markers in patients after myocardial infraction (MI). Atherosclerosis 194, e179-e184.

45. Wilson T, Singh AP, Vorsa N, et al. (2008) Human glycemic response and phenolic content of unsweetened cranberry juice. J Med Food 11, 46-54.

46. Borochov-Neori H, Judeinstein S, Greenberg A, et al. (2008) Phenolic antioxidants and antiatherogenic effects of Marula (Sclerocarrya birrea Subsp. caffra) fruit juice in healthy humans. J Agric Food Chem 56, 9884-9891.
47. Ruel G, Pomerleau S, Couture P, et al. (2005) Changes in plasma antioxidant capacity and oxidized low-density lipoprotein levels in men after short-term cranberry juice consumption. Metabolism 54, 856-861.

48. Oszmianski J \& Wojdylo A (2005) Aronia melanocarpa phenolics and their antioxidant activity. Eur Food Res Technol 221, 809-813.

49. Brown AA \& Hu FB (2001) Dietary modulation of endothelial function: implications for cardiovascular disease. Am J Clin Nutr 73, 673-686.

50. Sattar N \& Ferns G (2005) Endothelial dysfunction. In Cardiovascular Disease: Diet Nutrition and Emerging Risk Factors, pp. 63-77 [S Stanner, editor]. Oxford: Blackwell Science.

51. Stein JH, Keevil JG, Wiebe DA, et al. (1999) Purple grape juice improves endothelial function and reduces the susceptibility of LDL cholesterol to oxidation in patients with coronary artery disease. Circulation 100, 1050-1055.

52. Davidson MH, Maki KC, Dicklin MR, et al. (2009) Effects of consumption of pomegranate juice on carotid intima-media thickness in men and women at moderate risk for coronary heart disease. Am J Cardiol 104, 936-942.

53. Aviram M, Rosenblat M, Gaitini D, et al. (2004) Pomegranate juice consumption for 3 years by patients with carotid artery stenosis reduces common carotid intima-media thickness, blood pressure and LDL oxidation. Clin Nutr 23, 423-433.

54. Chou EJ, Keevil JG, Aeschlimann S, et al. (2001) Effect of ingestion of purple grape juice on endothelial function in patients with coronary heart disease. Am J Cardiol 88, 553-555.

55. Clifton PM (2004) Effect of grape seed extract and quercetin on cardiovascular and endothelial parameters in high-risk subjects. J Biomed Biotechnol 2004, 272-278.

56. Koga T \& Meydani M (2001) Effect of plasma metabolites of $(+)$-catechin and quercetin on monocyte adhesion to human aortic endothelial cells. Am J Clin Nutr 73, 941-948.

57. Yamakoshi J, Kataoka S, Koga T, et al. (1999) Proanthocyanidin-rich extract from grape seeds attenuates the development of aortic atherosclerosis in cholesterol-fed rabbits. Atherosclerosis 142, 139-149.

58. Stoclet JC, Chataigneau T, Ndiaye M, et al. (2004) Vascular protection by dietary polyphenols. Eur J Pharmacol 500, 299-313.

59. Serraino I, Dugo L, Dugo P, et al. (2003) Protective effects of cyanidin-3-O-glucoside from blackberry extract against peroxynitrite-induced endothelial dysfunction and vascular failure. Life Sci 73, 1097-1114.

60. Youdim KA, Martin A \& Joseph JA (2000) Incorporation of the elderberry anthocyanins by endothelial cells increases protection against oxidative stress. Free Radic Biol Med 29, 51-60.

61. Sumner MD, Elliott-Eller M, Weidner G, et al. (2005) Effects of pomegranate juice consumption on myocardial perfusion in patients with coronary heart disease. Am J Cardiol 96, 810-814.

62. Franke AA, Cooney RV, Henning SM, et al. (2005) Bioavailability and antioxidant effects of orange juice components in humans. J Agric Food Chem 53, 5170-5178.

63. Kurowska EM, Spence JD, Jordan J, et al. (2000) HDLcholesterol-raising effect of orange juice in subjects with hypercholesterolemia. Am J Clin Nutr 72, 1095-1100.

64. Duthie SJ, Jenkinson AM, Crozier A, et al. (2006) The effects of cranberry juice consumption on antioxidant status and biomarkers relating to heart disease and cancer in healthy human volunteers. Eur J Nutr 45, 113-122.

65. George TW, Niwat C, Waroonphan S, et al. (2009) Effects of chronic and acute consumption of fruit- and vegetable-puree-based drinks on vasodilation, risk factors for CVD and the response as a result of the eNOS G298T polymorphism. Proc Nutr Soc 68, 148-161.

66. Aviram M \& Dornfeld L (2001) Pomegranate juice consumption inhibits serum angiotensin converting enzyme activity and reduces systolic blood pressure. Atherosclerosis 158, 195-198.

67. Clifford MN (2004) Diet-derived phenols in plasma and tissues and their implications for health. Planta Med 70, 1103-1114. 